\title{
Redescription of the Korean sandlance Hypoptychus dybowskii from Korea
}

\author{
Hyuck Joon Kwun ${ }^{*}$ (i) and Mi-Jin Yim
}

\begin{abstract}
Hypoptychus dybowskii, the Korean sandlance, is widespread in cold areas of the North Pacific. Although $\mathrm{H}$. dybowskii has been considered to occur on the coast of Hamgyeongnam-do in Korea, the species is also distributed along the coast of Goseong-gun, Gangwon-do, south of Hamgyeongnam-do in the eastern part of the Korean Peninsula on the basis of newly collected specimens. In addition, many Koreans confuse H. dybowskii and Ammodytes japonicus ( $=$ A. personatus for Korean specimens) because the Korean common name or dialect of both species is "Yang-mi-ri", yet the two species differ in their external morphology. Hypoptychus dybowskii differs from A. japonicus in the location of the origin of the dorsal fin and the number of dorsal and anal fin rays.
\end{abstract}

Keywords: Redescription, Misidentification, Hypoptychus dybowskii, Sand lance, Ammodytes personatus

\section{Background}

Fishes of the genus Hypoptychus Steindachner 1880 (family Hypoptychidae) occurs in cold areas of the North Pacific near Korea, Japan, and Russia (Froese and Pauly 2017). The single species of this genus, Hypoptychus dybowskii Steindachner 1880, has been recognized in those regions (Kim et al. 2005a; Senou 2013; Parin et al. 2014). In Korea, Mori and Uchida (1934) were the first to report H. dybowskii from the coast of Hamgyeongnam-do, North Korea, but no morphological description was provided. Subsequently, Chyung (1977) described the species morphology and distribution and defined the Korean common name as "Yang-mi-ri". Subsequently, many Korean ichthyologists regarded the distribution of this species in Korea as on the coast of the East Sea (Kim et al. 2005a; Kim et al. 2005b). However, no additional confirmed record of this species has been reported south of Hamgyeongnam-do, except that of Lee et al. (1997), for which confirmation is required. Another issue is the incorrect identification of this species. Chyung (1977) named Ammodytes personatus Girard 1856 (revised to Ammodytes japonicus Duncker and Mohr 1939 for Korean specimens by Kim et al. 2017), which is similar to $H$. dybowskii in external shape. In Korean, A. japonicus is called "Kka-na-ri"; however, Korean people who are not ichthyologists called this species "Yang-mi-ri" rather than

\footnotetext{
* Correspondence: kwunhj@hotmail.com

National Marine Biodiversity Institute of Korea, 75, 101 Jangsan-ro,

Janghang-eup, Seocheon-gun, Chungcheongnam-do 33662, South Korea
}

"Kka-na-ri". Subsequently, some researchers have used the incorrect scientific name or the Korean common name (Kim et al. 2008a; Lee et al. 2011; Kim et al. 2012). Providing wrong information can cause serious problems in communication and scholarship, so a correction is required.

Therefore, the present study provides a morphological description of $H$. dybowskii on the basis of new material from Korea and compares this species with $A$. japonicus (= A. personatus for Korean specimens) in terms of external morphology.

\section{Methods}

Two specimens of $H$. dybowskii were collected from Goseong-gun, Gangwon-do, Korean coast of the East Sea, with a hand net in May 2017. They were fixed as whole-body specimens in 99\% ethanol. Counts and measurements follow Hubbs and Lagler (2004) using digital vernier calipers (to the nearest $0.1 \mathrm{~mm}$ ). The fin rays were counted under a stereomicroscope (SZX16, Olympus, Japan). The specimens have been deposited at the National Marine Biodiversity Institute of Korea, Marine Fish Diversity (MFD).

\section{Results}

Hypoptychus dybowskii Steindachner 1880

(Korean name: Yang-mi-ri) (Figs. 1 and 2a)

Hypoptychus dybowskii Steindachner 1880: 158 (type locality: Peter the Great Bay); Mori and Uchida 1934: 31; 


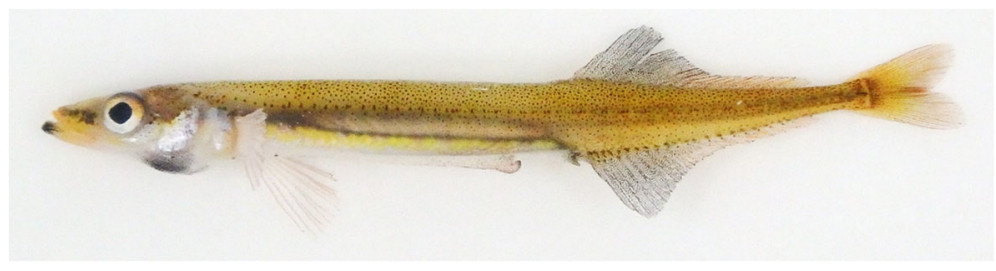

Fig. 1 Hypoptychus dybowskii, MFD-1052, 71.3 mm SL

Lindberg and Krasyukova 1975: 201; Kim et al. 2005a: 199; Senou 2013: 609; Parin et al. 2014: 203.

Hypoptychus steindachneri Franz 1910: 8 (type locality: Fukuura, Japan).

\section{Examined material}

MFD-1052-1053, two specimens, Machajin beach, Machajin-ri, Hyeonnae-myeon, Goseong-gun, Gangwon-do, Korea, hand net, 31 May 2017.

\section{Description}

Counts are provided in Table 1. Proportions as a percentage of standard length: head length 22.3-22.6; predorsal length 63.3-64.8; preanal length 65.4-66.8; body depth 7.3-8.4; caudal peduncle depth 2.8-3.0; caudal peduncle length 7.9-9.1; postorbital length 8.7-9.4; pectoral fin length 13.7-13.9. Proportions as a percentage of head length: eye diameter 26.4; snout length 34.0-35.2; interorbital width 24.5-25.8; suborbital width 10.1-10.7; upper jaw length 32.7-34.6. Body elongate, compressed. Head small and eyes large. Snout somewhat long and pointed. Mouth moderate and terminal. Anterior tip of lower jaw projects beyond anterior tip of upper jaw. Posterior tip of the maxilla does not reach anterior margin of eye. Small conical teeth on upper jaw. Interorbital region slightly wide and flat. Head and body naked. A single lateral line extending to caudal-fin base in a straight line. Dorsal fin located opposite to anal fin on posterior part of body; origin of dorsal fins just above that of anal fin. Dorsal and anal fins high anteriorly and gradually decreasing in height posteriorly. Pectoral fins slightly large. Caudal fin forked. Pelvic fin absent. Longitudinal dermal fin fold developed on ventral surface of body; its posterior tip in male hook-like.

\section{Coloration}

When fresh, head and body reddish-yellow and semi-transparent with small black dots (Figs. 1 and 2a). Black dots well developed on anterior region of lower jaw and ventral region of gill membrane. All fins semi-transparent. Membranes of dorsal and anal fins with small black melanophores. After alcohol fixation, head and body pale and whitish.

\section{Distribution}

Hypoptychus dybowskii occurs in the northern coastal waters of the East Sea, Korea (present study, Kim et al. 2005a), the Pacific and East Sea coasts of Japan (Senou 2013), and the Okhotsk Sea and East Sea coasts of Russia including Peter the Great Bay Lindberg and Krasyukova 1975.

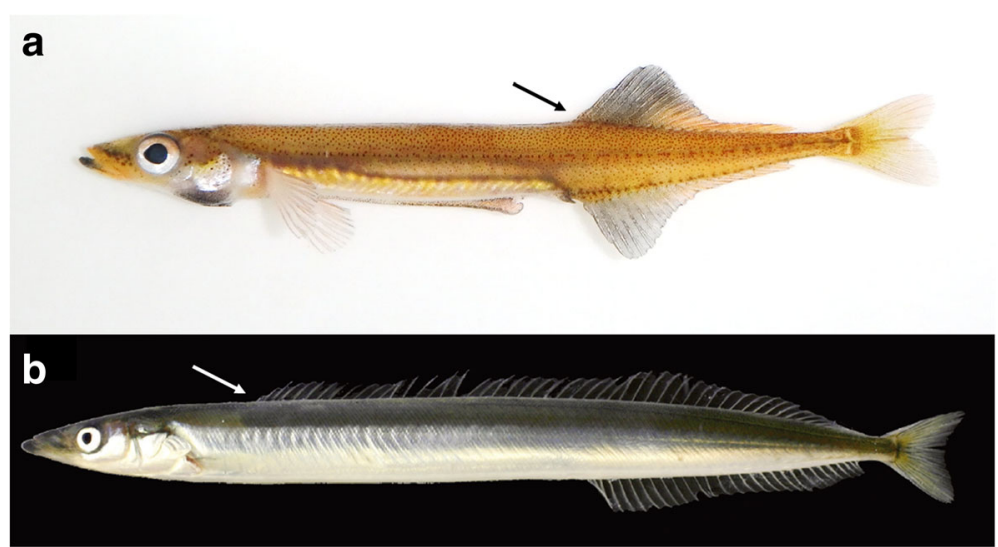

Fig. 2 External shapes. a Hypoptychus dybowskii (MFD-1053, 70.5 mm SL). b Ammodytes japonicus (cited in Orr et al. 2015 Figure 6C, FAKU 130765, $104.8 \mathrm{~mm} \mathrm{SL}$ ). Arrows indicate the origin of dorsal fin 
Table 1 Comparison of meristic characters of Hypoptychus dybowskii and Ammodytes japonicus

\begin{tabular}{|c|c|c|c|}
\hline & \multicolumn{2}{|c|}{ Hypoptychus dybowskii } & \multirow{2}{*}{$\begin{array}{l}\text { Ammodytes } \\
\text { personatus } \\
\text { Kim et al. (2008b) }\end{array}$} \\
\hline & Present study & Senou (2013) & \\
\hline Number of specimens & 2 & - & 90 \\
\hline Standard length (mm) & $70.5-71.3$ & - & $91.0-228.1$ \\
\hline \multicolumn{4}{|l|}{ Counts } \\
\hline Dorsal fin rays & 21 & $19-21$ & $53-60$ \\
\hline Anal fin rays & $21-22$ & $19-22$ & $27-33(n=89)$ \\
\hline Pectoral fin rays & 9 & $9-10$ & $13-16$ \\
\hline
\end{tabular}

\section{Discussion and conclusion}

The present study provides a morphological description of $H$. dybowskii on the basis of specimens collected from the coast of the East Sea, Goseong-gun, Gangwon-do, south of Hamgyeongnam-do. The present specimens can be identified as $H$. dybowskii in the family Hypoptychidae based on the following characters: absence of scales and pelvic fin; dorsal and anal fins without spines and located in the posterior region of the body; and elongate body (Nelson et al. 2016). The present specimens well agree with the original description of $H$. dybowskii in terms of body shape and the locations of the dorsal and anal fins (Steindachner 1880). Many people often confuse $H$. dybowskii and A. japonicus because the Korean common name or dialect "Yang-mi-ri" is applied to both species. Although they have a similar body shape, these two species possess different external morphologies. Hypoptychus dybowskii can be distinguished from $A$. japonicus by means of the location of the origin of the dorsal fin (behind to above anus in H. dybowskii vs. above the pectoral fin in A. japonicus) (Fig. 2), and the number of dorsal and anal fin rays (19-21 and 19-22, respectively, vs. 53-60 and 27-33, respectively) (Table 1) (Kim et al. 2005a; Kim et al. 2008b; Senou 2013). Furthermore, H. dybowskii is not exploited as a fisheries resource, but $A$. japonicus, which can easily be found in local fish markets in Korea, is commonly consumed in Gangwan-do. Therefore, the samples used in several studies (Kim et al. 2008a; Lee et al. 2011; Kim et al. 2012), which were collected from fish markets, are more likely to be $A$. japonicus than $H$. dybowskii.

\section{Funding}

This work was supported by the National Marine Biodiversity Institute of Korea Research Program (2018M00200).

Authors' contributions

Both authors read and approved the manuscript.

\section{Competing interests}

The authors declare that they have no competing interests.

\section{Publisher's Note}

Springer Nature remains neutral with regard to jurisdictional claims in published maps and institutional affiliations.

Received: 26 January 2018 Accepted: 16 May 2018

Published online: 18 September 2018

\section{References}

Chyung MK. The fishes of Korea. Seoul: II-Ji Sa Publishing; 1977.

Duncker G, Mohr E. Revision der Ammodytidae. Mitt Zool Mus Berl. 1939;24:8-31.

Franz V. Die japanischen Knochenfische der Sammlungen Haberer und Doflein. Abh Math-Phys Kl, K Bayer Akad Wiss. 1910:4:1-135.

Froese R, Pauly D. FishBase. 2017. http://fishbase.org. Accessed 18 Nov 2017.

Girard CF. Contributions to the ichthyology of the western coast of the United States, from specimens in the museum of the Smithsonian Institution. Proc Acad Nat Sci Phila. 1856;8:131-7.

Hubbs CL, Lagler KF. Fishes of the Great Lakes Region Revised ed. Ann Arbor: The University of Michigan Press; 2004.

Kim BM, Jung JH, Kim DS, Kim YM, Jeong IH. Inhibitory activity of intracellular lipid accumulation by various marine extracts in HepG2 cells. Korean J Food Sci Technol. 2012:44:362-6.

Kim GW, Kim GH, Kim JS, An HY, Hu GW, Park IS, Kim OS, Cho SY. Quality of fried fish paste prepared with sand-lance (Hypoptychus dybowskii) meat and propolis additive. J Fish Soc. 2008a;41:170-5.

Kim IS, Choi Y, Lee CL, Lee YJ, Kim BJ, Kim JH. Illustrated book of Korean fishes. Seoul: Kyo-Hak Publishing; 2005a.

Kim JK, Bae SE, Lee SJ, Yoon MG. New insight into hybridization and unidirectional introgression between Ammodytes japonicus and Ammodytes heian (Trachiniformes, Ammodytidae). PLoS One. 2017;12:e0178001.

Kim JK, Park JH, Kim YS, Kim YH, Hwang HJ, Hwang SJ, Lee SI, Kim TI. Geographic variations in Pacific sand eels Ammodytes personatus (Ammodytidae) from Korea and Japan using multivariate morphometric analysis. J Ichthyol. 2008b; 48:904-10.

Kim YU, Myoung JG, Kim YS, Han KH, Kang CB, Kim JK, Ryu JH. Marine fishes of Korea. 2nd ed. Hanguel: Busan; 2005b.

Lee JY, Park YJ, Chang YJ. Spawning and egg development of sand eel (Hypoptichus dybowskii). Dev Reprod. 1997;1:91-7.

Lee WS, Jeon JK, Byun HG. Characterization of a novel antioxidative peptide from the sand eel Hypoptychus dybowskii. Process Biochem. 2011;46:1207-11.

Lindberg GU, Krasyukova ZV. Fishes of the Sea of Japan and adjacent areas of the Sea of Okhotsk and the Yellow Sea. Part 4. Leningrad: Izdateljestvo Nauka, Leningradskoie Otdeleie; 1975.

Mori T, Uchida K. A revised catalogue of the fishes of Korea. J Chosen Nat Hist Soc. 1934;19:12-33.

Nelson JS, Greande TC, MVH W. Fishes of the world. 5th ed. Hoboken: John Wiley and Sons; 2016.

Orr JW, Wildes S, Kai Y, Raring N, Nakabo T, Katugin O, Guyon J. Systematics of North Pacific sand lances of the genus Ammodytes based on molecular and morphological evidence, with the description of a new species from Japan. Fish Bull. 2015;113:129-56.

Parin NV, Evseenko SA, Vasil'eva ED. Fishes of Russian Seas: Annotated catalogue. Moscow: KMK Scientific Press; 2014.

Senou H. Hypoptychidae. In: Nakabo T, editor. Fishes of Japan with pictorial keys. 3rd ed. Tokyo: Tokai University Press; 2013.

Steindachner F. Beitäge zur Kenntniss der Flussfische Südamerikas (II) und Ichthyologische Beiträge (IX). Anz Akad Wiss Wien, Math-nat Kl. 1880;17:157-9. 